\title{
PENGARUH IKLIM SEKOLAH TERHADAP KEDISIPLINAN DAN KREATIVITAS SISWA (STUDI KASUS DI SMP AL-AMANAH KELAS VII CINUNUK BANDUNG)
}

\author{
Rais Hafizh Itikar ${ }^{1}$, Jaja Jahari², Mohammad Sulhan ${ }^{3}$ \\ UIN Sunan Gunung Djati Bandung \\ raishafizhiftikar@yahoo.co.id ${ }^{1}$, jajajahari@uinsgd.ac.id², \\ muhsulhan@uinsgd.ac.id ${ }^{3}$
}

\begin{abstract}
ABSTRAK
Berdasarkan pengamatan yang dilakukan di kelas 7 SMP Al-Amanah Cinunuk Kabupaten Bandung, ternyata terdapat masalah berkenaan dengan kedisiplinan dan kreativitas siswa, yaitu masih rendahnya siswa dalam mentaati peraturan-peraturan sekolah dan kurangnya kreativitas siswa dalam proses kegiatan pembelajaran di sekolah. Padahal secara teoritis, kedisiplinan dan kreativitas sangat diperlukan dalam meningkatkan suatu kehidupan yang teratur dan meningkatkan prestasi dalam belajar karena sifatnya yang mengatur dan mendidik siswa untuk belajar dengan baik. Tujuan penelitian ini adalah untuk mengetahui pengaruh iklim sekolah terhadap kedisiplinan siswa, untuk mengetahui pengaruh iklim sekolah terhadap kreativitas siswa, dan untuk mengetahui pengaruh iklim sekolah terhadap kedisiplinan dan kreativitas siswa. Metode yang digunakan dalam penelitian ini adalah metode korelasi dengan pendekatan kuantitatif dengan berlandaskan pada filsafat positivisme. Hasil dari penelitian ini adalah bahwa pengaruh iklim sekolah terhadap kedisiplinan siswa sebesar 49,6\%. Sedangkan pengaruh iklim sekolah terhadap kreativitas siswa sebesar 25,3\%. Dan pengaruh iklim sekolah terhadap kedisiplinan dan kreativitas sebesar 51,7\%.
\end{abstract}

Kata Kunci: iklim, kedisiplinan, kreativitas

\section{ABSTRACT}

Based on observations made in 7th grade of Al-Amanah Cinunuk Junior High School in Bandung Regency, there were apparently problems with student discipline and creativity, namely the low student compliance with school rules and the lack of student creativity in the learning process at school. Whereas theoretically, discipline and creativity are needed in improving an orderly life and increasing achievement in learning because of its nature which regulates and educates students to learn well. The purpose of this study was to determine the effect of school climate on student discipline, to determine the effect of school climate on student creativity, and to determine the effect of school climate on student discipline and creativity. The method used in this research is the correlation method with a quantitative approach based on the philosophy of positivism. The results of this study are that the influence of the school climate on student discipline by $49.6 \%$. While the influence of the school climate on student creativity by $25.3 \%$. And the influence of the school climate on discipline and creativity by $51.7 \%$.

Keywords: climate, creativity, discipline

\section{PENDAHULUAN}

Proses pendidikan merupakan suatu sistem yang terdiri dari input, proses, dan output. Input merupakan siswa yang akan melaksanakan aktivitas belajar, proses merupakan kegiatan belajar mengajar, sedangkan output adalah hasil dari proses yang telah dilaksanakan. Pendidikan pun merupakan sebuah keberhasilan suatu negara, apabila pendidikan disebuah negara merosot, maka negara tersebut punya kecenderungan tidak 
berkembang, begitupun sebaliknya negara berkembang bisa dilihat dari pendidikannya yang baik. Sehingga pendidikan dikatakan sebagai ujung tombak dalam sebuah negara berkembang.

Sekolah merupakan lembaga pendidikan yang menampung siswa dan membinanya agar memiliki kemampuan, kecerdasan, dan keterampilan. Proses pendidikan memerlukan pembinaan secara terkoordinasi dan terarah yang diharapkan siswa dapat mencapai prestasi belajar yang maksimal sehingga tercapainya tujuan pendidikan. Sebagaimana yang tertuang dalam undang-undang sistem pendidikan Nasional No. 20 tahun 2013 sebagai berikut:

Pendidikan merupakan usaha sadar dan terencana untuk mewujudkan suasana belajar dan proses pembelajaran agar siswa secara aktif mengembangkan potensi dirinya untuk memiliki kekuatan spiritual keagamaan, pengendalian diri, kepribadian, kecerdasan, akhlak mulia, serta keterampilan yangdiperlukan dirinya, masyarakat, bangsa dan negara.

Pendidikan tersebut dapat dijelaskan bahwa kegiatan pendidikan adalah usaha sadar dalam kegiatan pengembangan potensi siswa secara optimal dan terpadu, baik dimensi spiritual keagamaan, pengendalian diri, kepribadian, kecerdasan, akhlak mulia serta keterampilan siswa baik untuk kehidupannya di masyarakat, bangsa dan negaranya.

Selanjutnya sekolah merupakan salah satu faktor yang mempengaruhi kepribadian dan konsep diri anak. Telah diakui dari berbagai pihak tentang peranan sekolah bagaimana sekolah ikut membina anak tentang kecerdasan, sikap, minat, dan sebagainya. Sekolah juga merupakan tempat individu untuk mendapatkan pengalaman bersosialisasi dengan lingkungan dan berkembang dengan teman sebayanya agar ia dapat tumbuh serta menjadi pribadi yang matang baik secara mental, emosional, dan sosial.

Sekolah adalah lembaga pendidikan formal yang merepresentasikan miniatur kehidupan serta lembaga yang dirancang untuk pengajaran siswa di bawah pengawasan seorang guru. Sebagian besar negara memiliki sistem pendidikan formal, yang umumnya wajib. Dalam sistem ini, siswa berkembang dan maju melalui serangkaian kegiatan sekolah. Tugas sekolah sangat penting dalam menyiapkan siswa untuk kehidupan masyarakat. Sekolah bukan sematamata sebagai konsumen, tetapi juga ia sebagai produsen dan pemberi jasa yang sangat erat hubungannya dengan pembangunan, maka dari itu keberadaan seorang guru di sekolah tidak terlepas dari iklim organisasi sedangkan kepemimpinan kepala sekolah mempunyai pengaruh yang 
positif atau negatif terhadap kedisiplinan dan kreativitas siswa. Hal tersebut akan memengaruhi proses kegiatan belajar mengajar di sekolah, yang menandakan bahwa iklim sekolah diarahkan untuk mengubah perilaku siswa ke arah yang positif dan lebih baik sesuai dengan potensi dan perbedaan yang dimiliki siswa. Iklim organisasi ini mempunyai pengaruh penting dalam proses pembelajaran baik itu positif atau negatif dengan kedisiplinan dan kreativitas personil di sekolah. Pengaruh yang dimaksud meliputi pengaruh antar guru dengan kepala sekolah, guru dengan guru, guru dengan siswa, maupun dengan orang tua siswa.

Menurut Saputra (2010) Dalam sebuah lembaga pendidikan, iklim budaya sekolah (organisasi) merupakan hal yang penting untuk dikaji secara mendalam, karena menunjukan kepribadian suatu organisasi termasuk organisasi sekolah. Iklim juga menggambarkan persepsi yang didukung bersama oleh anggota organisasi.

Mutmainah

menjelaskan bahwa iklim sekolah yang baik pula merupakan salah satu indikator sekolah efektif, yang dimana selalu menekankan pada keadaan rasa menyenangkan dari suasana yang terjadi di dalam sekolah, baik itu menyenangkan secara fisik maupun mencakup keseluruhan aspek internal sekolah. Oleh karena itu iklim sekolah harus mencakup kondisi sekolah dari segi keamanan, pembelajaran, hubungan antara pihak sekolah baik interpesonal maupun institusional.

Berdasarkan hasil studi yang dilakukan oleh Sobandi (dalam Putra, 2018), dalam jurnal pendidikan terhadap siswa kelas $X$ Administrasi Perkantoran di salah satu Sekolah Menengah Kejuruan (SMK) di Kota Bandung, bahwa minat belajar siswa masih belum optimal. Hal tersebut tergambar pada nilai capaian siswa pada 3 tahun ajaran mulai dari tahun ajaran 2013/2014 sampai tahun ajaran 2015/2016 yang belum memenuhi Kriteria Kelulusan Minimal (KKM) yang ditetapkan oleh sekolah, tergambar pula pada ketidak hadiran siswa tanpa keterangan yang masih tinggi. Iklim sekolah diduga sebagai salah satu faktor yang mempengaruhi minat belajar siswa, dengan adanya persentase menyatakan bahwa nilai koefisien determinasi dapat diketahui besarnya pengaruh iklim sekolah terhadap minat belajar siswa sebesar $27,85 \%$ sedangkan $72,15 \%$ dipengaruhi oleh faktor-faktor lain.

Adapun di SMP Islam AlAmanah memiliki iklim yang baik dengan terpenuhinya unsur-unsur penunjang iklim yang dibuktikan dengan terakreditasinya SMP Islam Al-Amanah ini dengan nilai $A$.

Djunaedi (dalam Aini, 2013) menjelaskan penelitian yang dilakukan Hans Jellen dari Universitas Utah, Amerika Serikat dan Klaus 
Urban dari Universitas Hannover, Jerman pada tahun 1987 terhadap anak-anak yang berusia 10 tahun yang berasal dari delapan negara. Anak Indonesia yang dijadikan sampel penelitian adalah sebanyak 50 anak-anak di Jakarta. Hasil penelitian tersebut menunjukkan bahwa tingkat kreativitas anak-anak Indonesia adalah yang terendah diantara anak-anak seusianya dari delapan negara lainnya. Urutan negara berdasarkan perolehan skor tertinggi hingga terendah yaitu Filipina, Amerika Serikat, Inggris, Jerman, India, Zulu, dan Indonesia.

SMP Islam Al-Amanah memiliki visi, misi dan tujuan sekolah yaitu unggul dalam kedisiplinan sekolah. Pada kenyataannya masih ditemukan banyak pelanggaran siswa, antara lain beberapa siswa yang terlambat masuk kelas, terlambat dalam upacara, tidak seragam dalam berpakaian dan ada beberapa siswa yang berbicara kasar, menghina, saling mengejek, bahkan masih ada beberapa siswa yang bawa handphone ke kelas sangat mengganggu proses pembelajaran.

Masalah lain yang sering muncul diantara para siswa SMP ini adalah adanya perkelahian antar siswa karena siswa saling mengejek. Dalam penelitian ini dipilih siswa kelas VII SMP Islam Al-Amanah Bandung sebagai subjek penelitian, karena di kelas VII tingkat kedisiplinan belajar siswa masih kurang. Hal ini disebabkan oleh latar belakang siswa dari beberapa SD yang kurang memperhatikan kedisiplinan siswa.

Berikut akan dicantumkan data yang diambil oleh peneliti pada tanggal 7 Oktober 2019.

Tabel 1. Data Keterlambatan Siswa Kelas VII Tahun 2018/2019

\begin{tabular}{|c|c|c|c|}
\hline No. & Bulan & $\begin{array}{c}\text { Total } \\
\text { Siswa }\end{array}$ & $\%$ \\
\hline 1 & Juli & 85 & $2,3 \%$ \\
\hline 2 & Agustus & 79 & $2,2 \%$ \\
\hline 3 & September & 52 & $1,4 \%$ \\
\hline 4 & \multicolumn{4}{|c|}{ Oktober } & 55 & $1,5 \%$ \\
\hline
\end{tabular}

Berdasarkan data di atas dengan jumlah subjek 136 siswa, maka diperoleh prosentase keterlambatan siswa bulan Juli $2.3 \%$, Agustus 2.2\%, September 1.4\% dan Oktober $1,5 \%$, sehingga diperoleh rata-rata keterlambatan siswa selama 4 bulan adalah 2.2\%. Dari hasil persentase diketahui bahwa keterlambatan siswa kelas VII (semester 1) mengalami ketidakstabilan. Dari hasil wawancara ada beberapa perilaku yang dilakukan oleh para siswa seperti membolos, terlambat masuk sekolah, kurangnya minat dan semangat selama berlangsungnya pelajaran menunjukkan bahwa kedisiplinan belajar yang mereka miliki cukup rendah. Hal tersebut tidak sesuai dengan kondisi fisik sekolah yang mendukung untuk proses belajar mengajar serta sarana dan prasaran yang tersedia, yaitu terdapat 12 ruang kelas, 1 
perpustakaan, 1 laboratorium IPA, 2 laboratorium komputer, 1 ruang OSIS, dan 1 lapangan olahraga.

\section{METODE PENELITIAN}

Dalam hal ini, peneliti menggunakan pendekatan penelitian kuantitatif. Pendekatan penelitian kuantitatif Sugiono (2011) mengartikan sebagai "metode penelitian yang berlandaskan pada filsafat positivisme, digunakan untuk meneliti pada populasi atau sampel tertentu, pengumpulan data menggunakan instrumen penelitian, analisis data bersifat kuantitatif/statistik, dengan tujuan untuk menguji hipotesis yang telah ditetapkan. Metode ini disebut sebagai metode positivistik karena berlandaskan pada filsafat positivisme. Metode ini sebagai metode ilmiah karena telah menemui kaidah-kaidah ilmiah yaitu konkrit/empiris, obyektif, terukur, rasional dan sistematis. Metode ini disebut metode kuantitatif karena data penelitian berupa angka-angka dan analisis menggunakan statistik.

Pengumpulan data dapat dilakukan dalam berbagai setting, berbagai sumber, dan berbagai cara. Sugiono (2011) Bila dilihat dari segi cara atau teknik pengumpulan data, maka teknik pengumpulan data dapat dilakukan dengan interview (wawancara), kuesioner (angket), dan observation (pengamatan), dan gabungan ketiganya.
Arikunto (2006) menyebutkan mengumpulkan data adalah mengamati variabel yang akan diteliti dengan metode interviu, tes observasi, kuesioner, dan dokumentasi. Dalam hal ini peneliti menggunakan teknik pengumpulan data melalui metode interview (wawancara), observation (pengamatan), kuesioner (angket), dan dokumentasi.

Wawancara digunakan sebagai teknik pengumpulan data apabila ingin melakukan studi pendahuluan untuk menemukan permasalahan yang harus diteliti, dan juga apabila peneliti ingin mengetahui hal-hal dari responden yang lebih mendalam dan jumlah respondennya sedikit/kecil.

Peneliti melakukan wawancara tersebut dengan kepala sekolah, guru bidang kurikulum, guru bidang kesiswaan, dan wali kelas di SMP Al-Amanah Bandung. Adapun wawancara yang dilakukan peneliti yaitu wawancara secara tidak terstruktur, sebagaimana yang telah dikemukakan oleh Sugiyono (2011) bahwa "wawancara tidak terstruktur adalah wawancara yang bebas dimana peneliti tidak menggunakan pedoman wawancara yang telah tersusun secara sistematis dan lengkap untuk pengumpulan datanya". Pedoman wawancara yang digunakan hanya berupa garis-garis besar permasalahan yang akan ditanyakan. 
Menurut Tanzeh (2009), observasi merupakan metode pengumpulan data yang menggunakan pengamatan terhadap obyek penelitian yang dapat dilaksanakan secara langsung maupun tidak langsung. Observasi dilakukan secara tidak terstruktur, karena fokus penelitian belum jelas sehingga peneliti melakukan pengamatan bebas dengan mencatat apa saja yang menurut peneliti penting. Selanjutnya apabila fokus penelitian sudah jelas, maka peneliti menggunakan observasi terstruktur, artinya peneliti menggunakan pedoman observasi.

Maka dalam penelitian ini penulis menggunakan pengamatan langsung terhadap lokasi penelitian khususnya di kelas VII dan keadaan guru, siswa, sarana dan prasarana belajar, serta letak geografis SMP AlAmanah Bandung untuk mengetahui iklim sekolah, kedisiplinan belajar siswa dan kreativitas siswa. Teknik pengumpulan data observasi digunakan untuk memperoleh data proses jalannya pengisian angket.

Kuesioner menurut Sugiono

$$
\text { merupakan teknik }
$$

pengumpulan data yang dilakukan dengan cara memberi seperangkat pertanyaan atau pernyataan tertulis kepada responden untuk dijawabnya. Instrumen angket ini digunakan untuk mengetahui rumusan masalah tentang pengaruh iklim sekolah terhadap kedisiplinan dan kreativitas siswa, yang akan disebarkan kepada siswa kelas VII SMP Al-Amanah Bandung sebagai sampel dalam penelitian ini.

Peneliti membuat kuesioner berupa pertanyaan atau pertanyaan tertutup atau terbuka yang diberikan kepada responden (siswa SMP kelas VII Al-Amanah Bandung) secara langsung. Angket variabel iklim sekolah, kedisiplinan dan kreativitas diajukan sebanyak 20 item pertanyaan atau pernyataan dengan berbentuk skala Likert untuk pertanyaan positif maka siswa akan memperoleh skor 5 apabila menjawab selalu, skor 4 apabila menjawab sering, skor 3 apabila menjawab kadang-kadang, skor 2 apabila menjawab jarang, dan skor 1 apabila menjawab tidak pernah. Sedangkan untuk pertanyaan negatif maka skor yang diperoleh adalah sebaliknya.

Data hasil penelitian berupa angka-angka yang diolah dengan bantuan analisis statistik yang relevan, maka antar variabel-variabel yang dijadikan objek penelitian harus jelas korelasinya sehingga dapat ditentukan pendekatan statistik yang akan digunakan sebagai pengolahan data, yang pada gilirannya hasil analisis dapat dipercaya (reliabilitas dan validitas). Oleh sebab itu mudah untuk digeneralisir, sehingga mudah untuk dibuat kesimpulan yang cukup jelas dan akurat. Langkah-langkah yang ditempuh dalam menganalisis data adalah : 
Uji validitas (kesahihan) adalah kualitas yang menunjukkan hubungan antara suatu pengukuran (diagnosis) dengan arti atau tujuan kriteria belajar atau tingkah laku. Beberapa kriteria dapat dipilih untuk memperlihatkan keefektifan terhadap peramalan performance yang akan datang (yang akan terjadi), kriteria yang lain untuk menunjukkan status yang muncul, kriteria yang lain lagi untuk menimbulkan sifat-sifat yang representatif dari luasnya isi atau tingkah laku dan kriteria yang lain lagi untuk (melengkapi) penyediaan data untuk menunjang atau menolak beberapa teori psikologis (Purwanto, 2002).

$$
\text { Melalui rumus SPSS }
$$

(Statistical Package for Social Science) version 20 dalam Trihendradi (2003) bahwa menentukan validitas dengan korelasi Product Moment (Pearson's Coefisient of Correlation) di katakan valid jika nilai signifikansi korelasi variabel total dengan masing-masing variabel pertanyaan memiliki nilai di bawah nilai alfa (0.05).

Uji Reliabilitas, selain dilakukan uji validitas, dilakukan pula uji reliabilitas untuk mengetahui tingkat keajegan (konsistensi) suatu angket. Suatu instrumen pengukuran dikatakan reliabel jika pengukurannya konsisten dan cermat akurat. Uji reliabel instrumen dilakukan dengan tujuan untuk mengetahui konsisten dari instrumen sebagai alat ukur, sehingga hasil suatu pengukuran dapat dipercaya.

Adapun untuk uji reliabilitas menggunakan rumus alpha untuk mengukur sebuah instrumen dapat di percaya atau tidak, dapat di ukur dengan rumus alpha-cronbach Trihendradi (2003) apabila instrumen tersebut menghasilkan ukuran yang konsisten digunakan untuk mengukur berurangkali, dan katakan andal bila memiliki nilai alpha Cronbach > dari 0.6.

Uji Normalitas dari data yang telah diketahui validitas dan reliabilitasnya, maka data tersebut di uji normalitasnya. Pengujian normalitas dilakukan untuk mengetahui normal tidaknya suatu distribusi data. Hal ini penting diketahui berkaitan dengan ketetapan pemilihan uji statistic yang akan dipergunakan. Misalnya uji parametrik mengsyaratkan bahwa data harus berdistribusi normal. Apabila distribusi data tidak normal, maka disarankan untuk menguji dengan uji non parametric.

Lokasi Penelitian ini dilakukan

di SMP Al-Amanah. Adapun yang menjadi objek penelitian ini adalah siswa kelas VII dengan jumlah sampel 64 orang. Alasan penelitian ini dilakukan di kelas VII karena adanya sumber data yang menarik untuk diteliti terkait permasalahan penelitian yakni pengaruh iklim sekolah terhadap kedisiplinan dan kreativitas siswa selain itu pada dasarnya penulis melakukan 
penelitian hanya dikelas VII ini dilatar belakangi karena di kelas VII tingkat kedisiplinan belajar siswa masih kurang. Hal ini disebabkan oleh latar belakang siswa dari beberapa SD yang kurang memperhatikan kedisiplinan dan pemilihan sekolah yang sebenarnya.

Penelitian ini bertujuan untuk menguji apakah ada pengaruh iklim sekolah terhadap kedisiplinan dan kreativitas siswa. Penelitian ini diawali dengan mengkaji teori-teori dan pengetahuan yang sudah ada sehingga muncul sebab permasalahan.

\section{HASIL PENELITIAN}

Seperti yang peneliti ketahui bahwa tujuan dari penelitian ini adalah ingin mengetahui bagaimana pengaruh iklim sekolah terhadap kedisiplinan dan kreativitas siswa kelas 7 di SMP Al-amanah Cinunuk Bandung.

Hasil analisis uji normalitas data hasil penelitian dimaksudkan untuk memberikan gambaran umum mengenai hasil penyebaran data yang diperoleh apakah data yang disebarkan berdistribusi normal atau sebaliknya. Untuk mengetahui hasil uji normalitas sebagaimana tercantum dalam tabel 2 .

Tabel 2.

Tests of Normality

\begin{tabular}{|c|c|c|c|c|c|c|c|}
\hline & \multirow{2}{*}{$\begin{array}{c}\text { Variabel } \mathrm{Y}_{1} \\
\text { (Kedisiplinan) }\end{array}$} & \multicolumn{3}{|c|}{ Kolmogorov-Smirnov $^{f}$} & \multicolumn{3}{|c|}{ Shapiro-Wilk } \\
\hline & & Statistic & $\mathrm{df}$ & Sig. & Statistic & Df & Sig. \\
\hline \multirow{16}{*}{$\begin{array}{c}\text { Variabel X } \\
\text { (Iklim Sekolah) }\end{array}$} & 61 & .200 & 3 & . & .995 & 3 & .862 \\
\hline & 63 & .198 & 5 & $.200^{*}$ & .945 & 5 & .703 \\
\hline & 65 & .260 & 2 & . & & & \\
\hline & 66 & .260 & 2 & . & & & \\
\hline & 67 & .260 & 2 & . & & & \\
\hline & 68 & .328 & 3 & . & .871 & 3 & .298 \\
\hline & 69 & .355 & 5 & .038 & .759 & 5 & .036 \\
\hline & 70 & .328 & 3 & . & .871 & 3 & .298 \\
\hline & 71 & .294 & 4 & . & .817 & 4 & .137 \\
\hline & 73 & .260 & 4 & . & .827 & 4 & .161 \\
\hline & 74 & .260 & 2 & . & & & \\
\hline & 75 & .265 & 5 & $.200^{*}$ & .908 & 5 & .458 \\
\hline & 78 & .253 & 3 & . & .964 & 3 & .637 \\
\hline & 80 & .276 & 3 & . & .942 & 3 & .537 \\
\hline & 87 & .260 & 2 & . & & & \\
\hline & 88 & .260 & 2 & . & & & \\
\hline
\end{tabular}

*. This is a lower bound of the true significance.

Tabel tests of normality, dengan interval kepercayaan 95\%, maka nilai $\alpha=5 \%$ (0.005). Hasil uji normalitas di atas, baik dengan metode maupun Shapiro-Wilk, dapat dilakukan dengan melihat nilai Sig. apabila nilai Sig. $>\alpha$ maka distribusinya normal. Akan tetapi, jika sebaliknya tidak normal, maka 
hasil analisis terlihat nilai Sig. $<\alpha$ maka distribusi tidak normal.

Output dari SPSS 20 dengan metode kolmogorov-Smirnov maupun Shapiro-Wilk dapat dilakukan dengan melihat dan membandingkan nilai Sig. dengan nilai $\alpha(0,005)$. Berdasarkan hasil perhitungan dapat diketahui bahwa seluruh nilai Sig. baik pada metode Kolmogorov-Smirnov maupun Shapiro-Wilk lebih besar nilainya dibandingkan dengan nilai $\alpha$. Pada metode Kolmogorov-Smirnov secara matematis dapat dituliskan nilai sig. $0.200,0.038$ dan $0.200>$ dari 0.005 . Begitupun pada metode ShapiroWilk secara matematis nilai sig. dapat dituliskan 0.862, 0.703, 0.298, 0.036, $0.298,0.137,0.161,0.458,0.637$, $0.537)>\alpha(0,005)$, sehingga dapat disimpulkan bahwa datanya berdistribusi normal pada taraf kepercayaan $5 \%$.

Tabel 3.

Tests of Normality

\begin{tabular}{|c|c|c|c|c|c|c|c|}
\hline & \multirow{2}{*}{$\begin{array}{l}\text { Variabel Y2 } \\
\text { (Kreativitas) }\end{array}$} & \multicolumn{3}{|c|}{ Kolmogorov-Smirnovc } & \multicolumn{3}{|c|}{ Shapiro-Wilk } \\
\hline & & Statistic & df & Sig. & Statistic & df & Sig. \\
\hline \multirow{15}{*}{$\begin{array}{c}\text { Variabel X } \\
\text { (Iklim Sekolah) }\end{array}$} & 54.00 & .260 & 2 & . & & & \\
\hline & 55.00 & .183 & 7 & $.200^{*}$ & .947 & 7 & .704 \\
\hline & 58.00 & .208 & 3 & . & .992 & 3 & .826 \\
\hline & 59.00 & .260 & 2 & . & & & \\
\hline & 63.00 & .260 & 2 & . & & & \\
\hline & 64.00 & .257 & 8 & .130 & .806 & 8 & .033 \\
\hline & 67.00 & .260 & 2 & . & & & \\
\hline & 70.00 & .304 & 3 & . & .907 & 3 & .407 \\
\hline & 71.00 & .343 & 3 & . & .842 & 3 & .220 \\
\hline & 76.00 & .260 & 2 & . & & & \\
\hline & 78.00 & .289 & 4 & . & .864 & 4 & .275 \\
\hline & 80.00 & .260 & 2 & . & & & \\
\hline & 82.00 & .260 & 2 & . & & & \\
\hline & 83.00 & .260 & 2 & . & & & \\
\hline & 86.00 & .308 & 4 & . & .888 & 4 & .376 \\
\hline
\end{tabular}

*. This is a lower bound of the true significance.

Output dari SPSS 20 dengan metode kolmogorov-Smirnov maupun Shapiro-Wilk dapat dilakukan dengan membandingkan nilai Sig. dengan nilai $\alpha(0,005)$. Berdasarkan hasil perhitungan dapat diketahui bahwa seluruh nilai Sig. baik pada metode KolmogorovSmirnov maupun Shapiro-Wilk lebih besar nilainya dibandingkan dengan nilai $\alpha$. Pada metode Kolmogorov-
Smirnov secara matematis dapat dituliskan nilai sig. 0.200 dan $0.130>$ dari 0.005. Begitupun pada metode Shapiro-Wilk lebih besar lagi nilai sig. dapat dituliskan 0.704, 0.826, 0.033, $0.407,0.220,0.275,0.376>\alpha$ $(0,005)$, sehingga dapat disimpulkan bahwa datanya berdistribusi normal pada taraf kepercayaan $5 \%$. 
Tabel 4.

Tests of Normality

\begin{tabular}{|c|c|c|c|c|c|c|c|}
\hline & \multirow{2}{*}{$\begin{array}{c}\text { Variabel Y2 } \\
\text { (Kreativitas) }\end{array}$} & \multicolumn{3}{|c|}{ Kolmogorov-Smirnovc } & \multicolumn{3}{|c|}{ Shapiro-Wilk } \\
\hline & & Statistic & $\mathrm{Df}$ & Sig. & Statistic & $\mathrm{df}$ & Sig. \\
\hline \multirow{15}{*}{$\begin{array}{c}\text { Variabel Y1 } \\
\text { (Kedisiplinan) }\end{array}$} & 54.00 & .260 & 2 & . & & & \\
\hline & 55.00 & 219 & 7 & $.200^{*}$ & .934 & 7 & .586 \\
\hline & 58.00 & 241 & 3 & . & 974 & 3 & .688 \\
\hline & 59.00 & 260 & 2 & . & & & \\
\hline & 63.00 & 260 & 2 & . & & & \\
\hline & 64.00 & .223 & 8 & $.200^{*}$ & .943 & 8 & .642 \\
\hline & 67.00 & .260 & 2 & . & & & \\
\hline & 70.00 & .292 & 3 & . & .923 & 3 & .463 \\
\hline & 71.00 & 181 & 3 & . & 999 & 3 & .942 \\
\hline & 76.00 & .260 & 2 & . & & & \\
\hline & 78.00 & .329 & 4 & . & .895 & 4 & .406 \\
\hline & 80.00 & 260 & 2 & . & & & \\
\hline & 82.00 & 260 & 2 & . & & & \\
\hline & 83.00 & .260 & 2 & 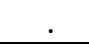 & & & \\
\hline & 86.00 & .408 & 4 & . & .737 & 4 & .029 \\
\hline
\end{tabular}

*. This is a lower bound of the true significance.

Berdasarkan uji normalitas yang telah dicantumkan dalam tabel-tabel di atas, dapat dilihat bahwa nilai sig. > nilai $\alpha$ (0.005), sehingga dapat disimpulkan sebaran semua data variabel $X \quad$ (iklim sekolah), $Y_{1}$ (kedisiplinan) dan $Y_{2}$ (kreativitas siswa) berdistribusi normal.

\section{PEMBAHASAN}

Hasil analisis kuantitatif dengan spss 20 menunjukan bahwa hipotesis pertama sesuai dengan yang telah diajaukan dalam penelitian ini dugaanya adalah terdapat pengaruh signifikan iklim sekolah atau (variabel X) terhadap kedisiplinan (Variabel Y) akhirnya terbukti berarti aktor iklim sekolah jelas mempengaruhi kedisiplinan siswa belajar disekolah. dugaanya adalah terdapat pengaruh signifikan iklim sekolah atau (variabel X) terhadap kreativitas siswa (Variabel
Y2) akhirnya terbukti hal ini dapat dijelaskan bahwa dalam iklim sekolah akan menimbulkan terciptanya belajar dengan baik.

Hipotesis ketigapun terbukti dugaanya yaitu terdapat pengaruh signifikan kedisiplinan (variabel Y1) terhadap kreativitas siswa (Variabel Y2). pengaruh ini dapat dijelaskan bahwa disiplin belajar merupakan kepatuhan untuk menghormati dan melaksanakan suatu sistem yang mengharuskan orang tunduk kepada keputusan, perintah, atau peraturan yang berlaku di sekolah.

\section{SIMPULAN}

Berdasarkan hasil dari deskripsi data dan pengujian hipotesis yang telah dilakukan tentang pengaruh iklim sekolah terhadap kedisiplinan dan kreativitas siswa adalah: 
Terdapat pengaruh iklim sekolah terhadap kedisiplinan siswa kelas VII di SMP Al-Amanah Bandung dalam tabel correlations dan tabel Model Summary ( $R$ ) diperoleh nilai koefisien korelasi sebesar 0.705 dengan korelasi kuat berada pada interval antara $0.60-0.79$. Uji hipotesisnya menunjukkan hipotesis alternatif $(\mathrm{Ha})$ diterima dengan membandingkan nilai Sig. (0.002) lebih kecil dari $\alpha$ (0.05). Uji besarnya pengaruh yang ditunjukkan dengan $R$ Square memiliki nilai sebesar 0.496 atau $49.6 \%$ yang menunjukkan besarnya pengaruh variabel iklim sekolah terhadap kedisiplinan belajar siswa. Terdapat pengaruh yang signifikan iklim sekolah terhadap kreativitas siswa kelas VII, hal ini terbukti dengan diperolehnya nilai koefisien korelasi sebesar 0.503 termasuk korelasi sedang sehingga berada pada daerah interval anatar 0.40 - 0.59. Uji hipotesisnya menunjukkan hipotesis alternatif $(\mathrm{Ha})$ diterima dengan membandingkan nilai Sig. (0.002) lebih kecil dari $\alpha$ (0.05). Uji besarnya pengaruh yang ditunjukkan dengan $R$ Square memiliki nilai sebesar 0.253 atau $25.3 \%$ yang menunjukkan besarnya pengaruh variabel iklim sekolah terhadap kreativitas belajar siswa kelas VII. Pengaruh kedisiplinan terhadap kreativitas belajar siswa memiliki pengaruh yang sedang dengan ditunjukkan hasil nilai koefisien korelasi sebesar 0.542 berada pada daerah interval antara $0.40-0.59$.
Sedangkan uji hipotesisnya menunjukkan hipotesis alternatif $(\mathrm{Ha})$ diterima dengan membandingkan nilai Sig. (0.000) lebih kecil dari $\alpha$ $(0,05)$. Uji besarnya pengaruh yang ditunjukkan dengan $R$ Square memiliki nilai sebesar 0.293 atau $29.3 \%$ yang menunjukkan besarnya pengaruh variabel kedisiplinan terhadap kreativitas belajar siswa. Terdapat pengaruh yang signifikan iklim sekolah secara bersamaan terhadap kedisiplinan dan kreativitas belajar siswa kelas VII, ditunjukkan dengan hasil pengujian koefisien korelasi ganda (R) sebesar 0.719 dengan tingkat korelasi kuat karena berada pada daerah interval antara 0.60 0.79 sehingga terdapat hubungan yang signifikan antara iklim sekolah secara bersamaan dengan kedisiplinan dan kreativitas siswa. Analisis uji hipotesisnya menunjukkan hipotesis alternatif $(\mathrm{Ha})$ diterima dengan membandingkan nilai Sig. (0.003) lebih kecil dari a (0.05). Sedangkan uji besarnya pengaruh diperoleh sebesar 51.7\% (R Square).

\section{DAFTAR PUSTAKA}

Aini, Nabila Qurrotu. 2016. Studi Deskriptif terhadap Siswa Kelas Tinggi Sekolah Dasar di Sekolah Alam Bandung Universitas Pendidikan Indonesia, (repository.upi.edu.perpustaka an, 2016)

Arikunto, Suharsimi. 2006. Penelitian Tindakan Kelas. Jakarta: Bumi Aksara. 
Mutmainah. 2017. Perilaku Kepemimpinan, Iklim Sekolah dan Sekolah Efektif, dalam Jurnal Administrasi Pendidikan (Vol.XXIV No.1 April.2017).

Purwanto, Ngalim. 2002. PrinsipPrinsip dan Teknik Evaluasi Pengajaran. Bandung: Remaja Rosdakarya

Putra, Satria Dharma. 2018. Jurnal Pendidikan Manajemen Perkantoran Vol.1 No.2 Januari 2018, 71-77.

Saputra, Uhar Suhar. 2010. Administrasi Pendidikan. Bandung: Refika Aditama.

Sugiyono. 2011. Metode Penelitian Pendidikan Pendekatan Kuantitatif, Kualitatif, dan R\&D. Bandung: Alabeta.

Tanzeh, Ahmad. 2009. Pengantar Metode Penelitian, Yogyakarta: Teras.

Trihendradi, C. 2012. Step by Step SPSS 20 Analisis Data Statistik. Yogyakarta: Andi.

Undang-undang Sistem Pendidikan Nasional Nomor 20 tahun 2003 (Jakarta: Fokus Media, 2003). 